\title{
Investigating the effects of counseling programs on runaway youth
}

\author{
Mohammad Reza Iravani ${ }^{a^{*}}$ and Hossein Ebrhaimzadeh Asmin ${ }^{b}$
}

${ }^{a}$ Assistant Professor, Department of Social Work, Islamic Azad University Khomeinishahr Branch, Daneshjou Blvd, Iran

${ }^{b}$ Assistant Professor, Department of Anthropology, University of Sistan and Baluchestan, Zahedn, Iran

\section{CHRON I C L E ABSTRACT}

Article history:

Received October 28, 2013

Received in revised format

25 November 2013

Accepted 29 January 2014

Available online

January 302014

Keywords:

Runaway

Counseling programs

Youth

\begin{abstract}
This paper presents an empirical investigation to study the effects of counseling programs on reducing the runaway youth in Iran. The study selects a sample of 30 students and divides them into two groups of control and experiment. The first group is kept under eight sessions of social skills training and a questionnaire consists of various questions including confidence items is distributed among both groups after the training ends. The implementation of KolmogorovSmirnov has revealed that both pre and post-test data are normally distributed. In addition, the result of ANOVA test has revealed that training program could significantly improve runaway youth's confidence.
\end{abstract}

\section{Introduction}

Runaway is one of the most important issues in any modern societies where youth decide not to stay at home and live with their families. According to Hammer et al. (2002), between 1.6 and 2.8 million youth run away in a year and youth aged 12-17 are at higher risk for homelessness than adults are. Over $50 \%$ of youth in shelters and on the streets stated that their parents either asked them to leave or knew they were leaving but did not pay attention to the consequences of their actions. According to Molnar et al. (1998), over $80 \%$ of runaway and homeless girls stated having ever been sexually or physically abused. In addition, $34 \%$ of runaway youth, both girls and boys, stated sexual abuse before leaving home and forty-three percent of runaway youth stated physical abuse before leaving home. There are several reasons behind runaway youth such as parents' addiction, severe family misconducts such as child abuse (McRee, 2008; Slesnick, 2011), etc. Many teenagers who scape from their homes are endangered by several deceases (Allen et al. 1994) and they may lose their healthcare (Farrow et al., 1992). There are several studies on detecting most important reasons behind the youth's motivation for escaping from their homes.

*Corresponding author. Tel: +989130758065

E-mail addresses: iravani@iaukhsh.ac.ir (M. R. Iravani) 
According to Yates et al. (1998), runaway street youth are at bigger risk for several medical problems and of health-compromising behaviors including suicide and depression, prostitution, and drug use. Feitel et al. (1992) performed an empirical investigation on psychosocial background and behavioral and emotional disorders of homeless and runaway youth. Kennedy (1991) identified different indicators associated with behavioral and environmental variables, which could help in the development of intervention and prevention strategies for this population.

Al-Tayyib et al. (2014) examined the association between current prescription drug misuse and injection among runaway and homeless youth. Attar-Schwartz (2013) investigated runaway behavior among adolescents in residential care by studying the effect of personal characteristics, victimization experiences while in care, social climate, and institutional factors. Sanchez et al. (2006) presented a demographical investigation on the reasons behind runaway youth. Aratani and Cooper (2012) applied data from the National Longitudinal Survey of Youth 1997 to study the relationship between running away from home between the ages of 12 and 14 and dropping from high school among youth. Propensity score matching was conducted in estimating the impact of running away on high school dropout while controlling for confounding factors. The findings recommended that having runaway-homeless episodes had a detrimental impact on academic achievement.

\section{The proposed study}

This paper presents an empirical investigation to study the effects of counseling programs on reducing the runaway among youth in Iran. The study selects a sample of 30 students and they were divided into two groups of control and experiment. The first group is kept under eight sessions of social skills training and a questionnaire consists of various questions including confidence items is distributed among both groups after the training ends. The implementation of Kolmogorov-Smirnov has revealed that both pre and post-test data are normally distributed. Table 1 demonstrates the summary of our computations.

Table 1

The summary of Kolmogorov-Smirnov

\begin{tabular}{lcc}
\hline Research variable & K-S-Z & P-value \\
\hline Pre-test & 0.555 & 0.917 \\
Post-test & 0.809 & 0.530 \\
\hline
\end{tabular}

In addition, Table 2 shows details of our findings on mean and standard deviation of the scores measured.

Table 2

The summary of mean and standard deviation of the survey

\begin{tabular}{lcccc}
\hline & \multicolumn{3}{c}{ Pre-test } & \multicolumn{2}{c}{ Post-test } \\
\cline { 2 - 5 } & Mean & Standard deviation & Mean & Standard deviation \\
\hline Control & 42.2667 & 13.81752 & 45.3333 & 11.12055 \\
Experiment & 46.6000 & 8.55069 & 61.4000 & 12.88853 \\
\hline
\end{tabular}

As we can observe from the results of Table 2, there is an increase on means of post-test compared with pre-test.

\section{The results and conclusion}

The implementation of this survey uses analysis of variance to measure the effect of training programs on improving teenagers' social skills as well as their confidence. Table 3 demonstrates the summary of our findings. 
Table 3

The summary of ANOVA test between pre-test and post-test figures

\begin{tabular}{cccccc}
\hline Variable & Df & Mean of squares & F & P-value & The effect \\
\hline Pre-test & 1 & 767.116 & 8.331 & 0.001 & 0.236 \\
Group & 1 & 2151.969 & 23.37 & 0.001 & 0.464 \\
\hline
\end{tabular}

According to the results of Table 3, counseling program influences on the sample of our survey and it has been able to improve their confidence. There is no doubt that runaway youth may influence society in terms of lowering the rate of highly educated people. According to (Aratani \& Cooper, 2012), running away from home may influence high school graduation rates. The effect of runaway behavior is bigger for youth who run away several times than those who run away a single time. Therefore, this issue needs to be considered in governmental level. There must be more awareness about the consequences of runaway youth so that families could take necessary actions against it. We believe prevention is more important than medication so we need to do more studies on detecting real causes of runaway youth.

\section{Acknowledgement}

The author would like to thank the teenagers who cordially accepted to participate in our survey. Author is also delighted for the comments on earlier version of this paper, which improved the quality of this paper.

\section{References}

Allen, D. M., Lehman, J. S., Green, T. A., Lindegren, M. L., Onorato, I. M., \& Forrester, W. (1994). HIV infection among homeless adults and runaway youth, United States, 1989-1992. Aids, 8(11), 1593-1598.

Al-Tayyib, A. A., Rice, E., Rhoades, H., \& Riggs, P. (2014). Association between prescription drug misuse and injection among runaway and homeless youth. Drug and alcohol dependence, 134, 406-409.

Aratani, Y., \& Cooper, J. L. (2012). The effects of runaway-homeless episodes on high school dropout. Youth \& Society. Doi: 10.1177/0044118X12456406.

Attar-Schwartz, S. (2013). Runaway behavior among adolescents in residential care: The role of personal characteristics, victimization experiences while in care, social climate, and institutional factors. Children and Youth Services Review, 35(2), 258-267

Farrow, J. A., Deisher, R. W., Brown, R., Kulig, J. W., \& Kipke, M. D. (1992). Health and health needs of homeless and runaway youth: A position paper of the Society for Adolescent Medicine. Journal of Adolescent Health, 13(8), 717-726.

Feitel, B., Margetson, N., Chamas, J., \& Lipman, C. (1992). Psychosocial background and behavioral and emotional disorders of homeless and runaway youth. Hospital \& Community Psychiatry, 43(2), 155-159.

Greene, J. (1995). Youth with Runaway, Throwaway, and Homeless Experiences: Prevalence, Drug Use, and Other At-Risk Behaviors Research Triangle Institute. HHS. ACF - ACYF.

Hammer, H., Finkelhor, D., \& Sedlak, A. (2002). Runaway / Thrownaway Children: National estimates and characteristics. National Incidence Studies of Missing, Abducted, Runaway, and Thrownaway Children. Office of Juvenile Justice and Delinquency Prevention.

Kennedy, M. R. (1991). Homeless and runaway youth mental health issues: No access to the system. Journal of Adolescent Health, 12(7), 576-579.

McRee, N. (2008). Child abuse in blended households: Reports from runaway and homeless youth. Child Abuse \& Neglect, 32(4), 449-453.

Molnar, B., Shade, S., Kral, A., Booth, R., \& Watters, J. (1998). Suicidal behavior and sexual / physical abuse among street youth. Child Abuse \& Neglect. 22(3), 213-222. 
Sanchez, R. P., Waller, M. W., \& Greene, J. M. (2006). Who runs? A demographic profile of runaway youth in the United States. Journal of Adolescent Health, 39(5), 778-781.

Yates, G. L., MacKenzie, R., Pennbridge, J., \& Cohen, E. (1988). A risk profile comparison of runaway and non-runaway youth. American Journal of Public Health, 78(7), 820-821.

Slesnick, N., Patton, R., \& Dashora, P. (2011). Runaway Teens. Encyclopedia of Adolescence, 276282 